\title{
Moving Masculinities: Memories and \\ Bodies Across Oceania
}

Margaret Jolly

On the cover of this journal we reproduce a detail from Hawaiian artist Carl F K Pao's Waikāne (reproduced in full on page vii). This painting distills many of the integrating themes of this issue, and especially the ideas of fluid, moving masculinities across the time and place of Oceania. It represents the close connections between pasts, presents, and futures in Oceania, imaging male ancestors whose powers course through living men, in a river of time as the male waters, Wai'ololi, sinuously curve toward the waters of women, in relations of difference, complementary connection, and regeneration. Kāne's 'o $\bar{o}^{\prime} \mathrm{o}$ or digging stick is here re-membered as a phallic spear of connection bursting open the spring waters of Waikāne, linking blood and semen, stone and water, earth and sky.

This is a powerful expression of Hawaiian masculinity, connecting embodied memories with gendered places and the sexualized flow of time. But, as with many essays in this special issue, its male potency emerges in relation-and sometimes in resistance-to the hegemonic forces of colonialism and contending imperial models of masculinity. Like Ty P Kāwika Tengan's essay, the content and context of Carl Pao's broader corpus of painting and sculpture meditates on Hawaiian masculinities as framed by United States imperialism and militarism.

The trio of indigenous Hawaiian and Māori male authors in this collection-Tengan, Walker, and Hokowhitu—all insist on the crucial importance of colonialism in the construction of indigenous masculinities in both past and present. Through his study of a group of young Hawaiian men, the Hui Panalā'au, recruited as colonists for the United States in the Equatorial Islands between 1935 and I942, Tengan reflects on the dialogue between the masculine scripts of US patriotism and indigenous sovereignty. Like many Hawaiians, Tengan's own family history is inti-

The Contemporary Pacific, Volume 20, Number I, I-24

(C) 2008 by University of Hawai' $i$ Press 
mately entangled with the military. In acts of "re-membering" the Hui Panalā'au, Tengan sees a fraught conversation between the celebration of the martial loyalty of American citizens and the celebration of indigenous warriorhood in the contemporary nationalist movement in which he is passionately engaged (see Tengan forthcoming).

Isaiah Helekunihi Walker is also intimately implicated in his subject, Hawaiian surfing, as an indigenous man and an enthusiastic surfer who grew up on O'ahu's North Shore. Walker critiques the prevailing portrait of Hawaiian "beachboys" as lazy, sensual, and emasculated. Rather, their muscular potency and sexual allure have consciously confronted haole (white) male power. The "boarder-lands" of the surf were perceived by many as a refuge from invasive colonial domination. Surfing is not just a sport that attracts the foreign tourist gaze but also an integral part of Hawaiian cultural resistance and renaissance.

Echoing Tengan's and Walker's analyses, Hokowhitu sees the hegemonic model of the Māori man as a hybrid created by colonialism, particularly through the colonial disciplines of education and sports like rugby, and not emasculated but hypermasculine (see also Hokowhitu 2004). As a Māori man, a scholar whose doctorate was awarded in both Māori studies and physical education, and a teacher in the School of Māori, Pacific, and Indigenous Studies at the University of Otago in Dunedin, Hokowhitu finds his research closely connected to his embodied life experience. His essay deconstructs the alleged "truth" of Māori patriarchy through both historical analysis and contemporary cultural criticism. For him, the film Whale Rider (Caro 2002) perpetuates a dangerously deceptive view of Māori patriarchy into the present. Thus, for all these authors, their stakes in re-membering history articulate with the contemporary cultural politics of being indigenous men in colonies dominated by white settlers.

Other authors in this special issue address Oceanic masculinities from a different position. Having grown up on Kwajalein Atoll in the I970s, Greg Dvorak reflects on how Marshallese land was transformed into American suburbia, into "home" for him as a "Kwaj kid" (see also Dvorak 2005). His essay combines autobiographical reflection with cogent analysis of the contending relations between American, Japanese, and Marshallese masculinities in the colonial theater of these "martial islands." Dvorak's analysis derives not just from his earlier lived experience but also from more recent ethnographic and archival research in the Marshall Islands, Hawai'i, and Japan, in which photography and filming have played a major part.

The essays by Kalissa Alexeyeff and Nicole George derive from life 
experience in the Cook Islands and Fiji as part of their doctoral research in anthropology and international relations, respectively. Alexeyeff brings her own talents as a dancer and her skills as a theorist of Western gender and sexuality to an analysis of "drag" in the Cook Islands. Despite her confessed personal and scholarly investment in the creative and fertile friction of cross-cultural encounters, she argues that on this occasion, crossdressing performances revealed the divergence, indeed repulsion, between Western and Oceanic modes of enacting gender and sexuality.

Nicole George's essay is focused less on her core doctoral subject-a historical consideration of regional women's organizations based in Suva (George 2006) - and more on a perplexing conundrum that emerged during her research in Fiji after the hostage crisis and the coup of 2000. As an Australian feminist with a passionate commitment to gender and sexual equality, George was troubled by the legitimation of violent forms of hypermasculinity by mainstream political and church leaders, simultaneous with the rejection of homosexuality as "un-Fijian," in the wake of the debates about the 1997 constitution.

This collection thus offers a distinctive congregation of younger voices from Oceania: indigenous male voices combined with those of an American man and two Australian women whose life experience and research passions have brought them to the region. This is a polyphonic chorus, but the articles are united by a common theme: Oceanic masculinities are best studied relationally and historically, between pasts, presents, and futures. Indigenous masculinities have been formed in relation to, as much as resistance against, hegemonic foreign models; and through such histories, hybrid hegemonies have emerged. How then does this set of articles engage with and extend previous writing on Oceanic masculinities and in the wider frame of global scholarship on masculinities?

\section{Singular Masculinity and Male Cults}

Although much has been written about men in Oceania, there has been far less theoretical interrogation of diverse and changing masculinities. For example, the large anthropological literature on male cults in Papua New Guinea, the Solomons, Vanuatu, and beyond, often inspired by universalist psychoanalytic models, has tended to conceive masculinity in the singular, formed in a traumatic separation from the mother and "polluting" feminine influences and transmitted through generations of men in perduring and painful traditions (see, eg, Allen I967, I998; Elliston 1995; Herdt 
I98I, I982, I984, I987; Layard I942; Silverman 200I). The end of male cults consequent on European pacification or conversion to Christianity has been lamented by some, portrayed as the "death of masculinity" or even the terminus of indigenous culture. ${ }^{1}$ This surely betrays a conflation of masculine ritual experience with "culture" (compare Strathern I988), and perhaps a propensity to perceive colonially induced transformations and broader cultural change as "emasculation" (but see below).

More comparative anthropologies in the past tended to approach masculinities through contrastive canonical figures of male leaders, as in Marshall Sahlins's famous but controversial opposition between Polynesian "chiefs" and Melanesian "big men" (1963), or in Maurice Godelier's contrasts between "big men" and "great men" in Highlands Papua New Guinea (I986), and related debates about different or divergent male powers, grounded in exchange, warfare, or ritual (Godelier and Strathern I99I). Although such studies proposed greater variety, this was still often framed in static typologies of "sorts of men" associated with different cultures or regions. Rarer and later were attempts to theorize diverse models of masculinities within and between "cultures," especially in the context of the labor trade to plantations (Keesing I985; Jolly I992b; Lipsett 1997), or to conceive masculinities as relational and historical (Brison I995; Kempf 2002), with dynamic and fluid connections between pasts and presents (Fife I995), and between indigenous and exogenous models (Knauft I997). An important precursor to the present collection is Geoffrey M White and Lamont Lindstrom's pathbreaking comparative historical anthropology of World War II, focused on relations between American and indigenous men (I989).

\section{Hegemonic Masculinities in Oceania?}

In the last decade, a rather different approach to Oceanic masculinities has emerged across diverse disciplines. This sees masculinities in the plural, in relational and historical terms, analyzing the power relations between dominant and alternative/subjugated modes of masculinities and connecting local and global ideals and realities. Much of this, such as two volumes emerging from New Zealand (Law, Campbell, and Dolan 1999; Worth, Paris, and Allen 2002), has been inspired by or in critical conversation with R W Connell (1995, 2000, 2005), and so it is worthwhile to articulate some of his more influential insights.

Connell deployed the notion of "hegemonic masculinity," using hege- 
mony after Antonio Gramsci to describe the masculinity that was broadly accepted as dominant and that became the measure by which other masculinities were adjudged less worthy or marginal (eg, working class and homosexual masculinities in Australia; see Donaldson I993). Hegemonic masculinities tend to follow the privileged scripts of culture, nation, and heterosexual desire (see Dvorak, this issue). Connell has stressed the way in which "being a man," and being a "proper man," is intimately grounded in the male body and sexuality, with privileged corporeal styles extruding those that are adjudged improper, feminized, or deviant (I995, 2002, 2005). The relation between the historical burden of sedimented pasts and present practices is in this view dialogical and reflexive: the weight of the past molds masculine being, but in changing present practices it is remembered, both re-embodied and recollected by individual subjects.

This approach might be related to Judith Butler's rather different conception of the performativity of gender (I990, I995), whereby the fictions not just of gender but also of biological sex are constantly iterated. Gender scripts exist before and beyond individual actors, but each embodied performance can both reproduce and subvert, unsettling the sedimented bodies of expectation through "gender trouble." In her early work (I990), Butler highlighted gender crossing and transsexuality to illustrate her claims, but, as she stressed in her later work (1995), hegemonic and heteronormative masculinities and femininities are equally a matter of constant if not consistent performativity (see Dvorak and Alexeyeff, this issue).

Gary Dowsett, in a recent appraisal presented at the "Moving Masculinities" conference from which these papers primarily derive, has also insisted on the need to remember not just gender but also sexuality in any analysis of masculinities (2006). Being a "proper" man in Australia means not being a "sissy," feminized, weak, or lacking in aggressive force, but also not being a "poofter," a man who desires other men. Thus, conforming to a heterosexual script, desiring women is equally a mark of a proper man, even if proper men constantly hang out with other men as "mates" in the homosocial worlds of work, pubs, and sports clubs.

The contributors to this special issue explore how these models of masculinities grounded in Australian sociology—or, more broadly, Western models of gender and sexuality-work in the Oceanic context. For, as Alexeyeff argues for the Cook Islands, repulsion rather than creative embrace can be generated by the "friction" (Tsing 2005) of past and present conjugations between Western and Oceanic models of gender and sexuality. Yet Western and Oceanic models are neither singular nor static. 
Many of the articles engage with the Australian theorists mentioned above, but they also bring a particularly Oceanic inflection to the dialogue. Inspired by Epeli Hau'ofa (I993), we use "Oceanic" to stress the connections and similarities between diverse experiences in different parts of the Pacific-Hawai'i, New Zealand, the Marshall Islands, the Cook Islands, and Fiji-and we thus talk of "moving masculinities" as we traverse the region. However, this collection is distinguished not only by its regional but also by its thematic and theoretical focus. In evoking the pun in re-membering, we are hoping to connect men's sexed bodies with individual and collective processes of memory, in continuing conversations between pasts and presents.

\section{Colonial Disciplines and Male Bodies in Hawai'i and New Zealand: Emasculation and Hypermasculinity, Hula AND HaKa}

The three essays by Tengan, Walker, and Hokowhitu engage fascinating comparisons of the divergent effects of "colonial disciplines" on Hawaiian and Māori men, and the ways in which these are re-membered in the present. These colonial disciplines include imperial knowledge from the epochs of exploration to white settlement and colonial practices of disciplining male bodies through the institutions of education, sport, and the military. In schools like Kamehameha and Te Aute, through games like rugby and baseball, in military corps including Hawaiians and the Mãori Battalions, hybrid hegemonies of masculinity were created. In these ways Hawaiian and Māori experience were similar. But there were also important differences. In Hawai' $i$, and especially after annexation by the United States, the predominant colonial discourse was of the feminization of the Islands and the emasculation of Hawaiian men. In New Zealand, by contrast, colonial discourses continuously stressed the hypermasculinity of Māori men and their martial character. This contrast can be traced back to early European representations from exploratory voyages, in which Polynesians in general, and high-ranking Hawaiians in particular, were seen as softer and more feminine, while Māori men and women were seen as harder and more masculine than other Polynesians, approximating even the peoples of Tanna and Malakula in the martial character of their collective life (see Jolly I992a, I997, 2007). Such differences plotted between peoples were amplified by contrasts between the warm and welcoming tropics and the colder austerity of New Zealand (see Forster I996). Contrary to Edward 
Said's suggestion that Orientalist discourses typically feminize colonized men (1978), Hawaiian men were seen as emasculated, while Māori men were rather seen as hypermasculine. The trio of essays by Tengan, Walker, and Hokowhitu explores this intriguing contrast.

Ty P Kāwika Tengan has consummately considered the way in which Hawaiian men, past and present, have contested images of their emasculated subjugation in his study of Hale Mua, a group of Hawaiian men who are deploying models of indigenous masculinity and warriorhood to fight for Hawaiian self-determination (Tengan forthcoming). Here he focuses on a very different group of Hawaiian men, the Hui Panalā'au, employed by the US government from I935 to I 942 to colonize the barren, uninhabited Equatorial Islands, ostensibly for commercial aviation links but secretly for strategic, military purposes. He shows how the men recruited for this task, initially all graduates of the elite Kamehameha Schools, were thought especially appropriate, not just because of their youthful vigor and muscularity but also because of their body discipline and obedient compliance. The disciplined bodies and minds of Kamehameha "boys" were contrasted with those of Waikiki "beach boys" who, though also models of muscular masculinity, were represented as lazy, unduly sexual, and rebellious (see Walker, this issue). ${ }^{2}$ The school cultivated the industrial discipline of manual vocations and the martial discipline of competitive sports and military drills.

Once in the Equatorial Islands, these men used their indigenous skills as surfers, sailors, and fishermen in personal survival and in pursuing their colonial mission: charting topography; recording winds, tides, and temperatures for the US military; and deploying colonial arts for the Bishop Museum, such as collecting "natural curiosities" like seashells. In contemporaneous representations, the bare-chested beauty of these men was celebrated, embodying "natural" Hawaiian men in their Oceanic element. Although their sexuality was subdued, journalists and letter writers of the period evoked the sensual allure of their bared, tanned bodies in ways similar to the treatment of Hawaiian "beach boys." Most of the men benefited from the experience in terms of better money, education, and recognition as US citizens, but some died tragically. The memories of the survivors are suffused with nostalgia for the strong homosocial bonds and mutual love and respect generated by enforced togetherness. Rituals of commemoration and a 2002 exhibition at the Bishop Museum simultaneously celebrated them as military heroes of the United States and of the Hawaiian nation. 
As Tengan suggests, such acts of re-membering are in dialogical relation with the revalorization of indigenous masculinities in the contemporary nationalist movement. The recuperation of indigenous martial arts by groups like Hale Mua contests perceptions of Hawaiian men as emasculated subjects, their masculinity dismembered as much as their land has been occupied (see Osorio 2002). Earlier colonial discourses that feminized the Hawaiian Islands were reenergized by the emergent culture of "militourism" from the mid-twentieth century, in which women were stereotypically cast as welcoming hosts and lovers, like the canonical "hula girl" (see Desmond 1999; Ferguson and Turnbull 1999; Kauanui 1998; Teaiwa I994; O’Brien 2006; Graham 2005). This colonial nexus created a dialogue between the hegemonic military masculinities of the United States and subjugated Hawaiian masculinities as either patriotic or resistant warriors.

The tendency to celebrate warriorhood in Hawaiian masculinity thus had a doubly colonial origin. But it was also compounded by the perceived dominance of women in the Hawaiian sovereignty movement (see Trask I993, I996), in comparison to Māori men, who were prominent from nineteenth-century anticolonial struggles like the Māori Wars to the cultural renaissance of Māori in Aotearoa/New Zealand from the I970s. Examining relations between Hawaiian and Māori men, in global and regional coalitions and in their mutual perceptions, Tengan sees Hawaiian men as diminished by the tendency to represent Māori by the male haka and Hawaiians by the female hula, encoding masculine resistance versus feminine accommodation (see Tengan 2002). Although there is a problem in plotting the complex real relations between men and women in nationalist movements through such canonical colonial scripts in which Aotearoa is masculinized and Hawai'i feminized, Tengan acutely perceives the continuing specter of "emasculation" of Hawaiian men, not just in relation to American colonizers but also in relation to Māori men.

But, as Isaiah Walker argues, we must be suspicious of that persistent colonial script that authors Hawaiian men as emasculated, indolent, and sensual (2005 and this issue). Walker's analysis focuses on those Hawaiian "beach boys" to whom the Kamehameha "boys" were invidiously contrasted. These beach boys-professional surfers and those who made a living through ocean sports-were denigrated from the early twentieth century as lazy and promiscuous. But, contrary to Jane Desmond's portrayal of them as feminized and benign pawns of tourist culture (I999), Walker suggests these men were "sexually alluring, manly, and actively 
responding to the changing society around them" (this issue, I04). He conceives the beach and especially the ocean as a "border/boarder zone" where the hegemonic relations of colonialism were unsettled, even flipped upside down in the fluid space of the waves. He stresses how, in the indigenous surfing cultures around Waikikī and the North Shore of O'ahu, Hawaiian men re-membered the ancient arts of surfboard riding and surfing, recollecting and re-embodying those skills, exemplified in the figure of Duke Kahanamoku. ${ }^{3}$ The ocean was, he argues, museum, sanctuary, and battleground. Beyond the beach, which Greg Dening privileged in his discussion of cross-cultural encounters (2004), Walker immerses us in the waves.

Hawaiian men active in surfing clubs like Hui Nalu and Waikīkì beachboys from the early I 900 s challenged haole hegemony in the ocean, projected by whites-only clubs like the Outrigger Canoe Club, whose members aimed to "learn all the secrets" of the Hawaiian surfer (and thus to compound imperial conquest by appropriation of indigenous knowledge). The men battled haole and foreign surfers for dominance in the waves through intense surfing competitions, but also challenged them on the shore, in physical confrontations with haole men and in sexual liaisons with haole women. The Hui Nalu surfers opened lucrative beach concession businesses in Waikìkî from I9I 5, as lifeguards, instructors, entertainers, singers, and tour guides. Some conjoined their surfing and sensual skills, performing erotic acrobatics in the ocean. Such men thus projected an image of Hawaiian men as intimidating to white men, both in their tough, daring physicality and in their sexual and romantic allure.

Unlike Desmond (I999), Walker does not see the Waikiki "beach boys" as soft, sexualized victims of the tourist industry, tantamount to "male prostitutes," but rather as empowered, anticolonial agents combining their skills as surfers and lovers. This resistance from the early twentieth century was perpetuated by later groups like the Hui O He'e Nalu of O'ahu's North Shore, which, in the I970s, fiercely challenged the presumptions of foreign professional surfers and were portrayed in both local newspapers and a John Wayne film as threatening "terrorists" (Walker 2005). The recuperation of martial arts from the I990s by groups like the Hale Mua reinforces this alternative indigenous view of Hawaiian men, not as emasculated and passive but as hypermasculine, threatening warriors (compare Linnekin 1997).

Yet hypermasculinity has been the dominant icon in popular portrayals of Māori men, by Pākehā and Māori. Brendan Hokowhitu's analysis of 
changing portraits of Māori men stresses the constant reiteration of their martial character. Like Tengan he sees warriorhood not as a perduring "tradition," but as a hybrid forged in the furnace of colonialism. Like Tengan he stresses the importance of elite colonial schools for Māori men in cultivating a "proper man," nobly consummate in war and the robust sport of rugby. The muscular disciplines of both war and sport were mimetic of martial Pākehā masculinities, which alike stressed an aggressive "hypermasculinity."

Elsewhere Hokowhitu has analyzed how rugby was central in the colonial relations of Māori and Pākehā men (2004; see also Diaz 2002). Māori men's alleged natural affinity for the sport elaborated earlier Enlightenment images of "natural man" and the "noble savage." The nobility of Māori warrior resistance to British colonialism was, however, offset by a negative appraisal of their violence toward women, allegedly symptomatic of their "ignoble savage" state for Pākehā settlers and scholars. The "real" Māori warriors of the past were often contrasted with the "degraded" Māori men of the settler colonial period. Colonial schools like Te Aute groomed elite Māori gentlemen, combining British and indigenous patriarchal traditions, legitimated by myths of the "Aryan Māori." Although longtime Te Aute Headmaster John Thornton advocated tennis and cricket rather than the violent contact sport of rugby, the latter soon became dominant and Te Aute graduates were prominent players in both the All Blacks and the New Zealand Māori rugby teams. Many became prominent as leaders in civil and military life. Only an elite minority attended such schools, while most Māori men were either uneducated or trained in the working class virtues of manual labor. Still, this elite, hybrid masculinity became hegemonic.

Hokowhitu is not so much concerned with the realities of Māori masculinities in the ancient, precolonial past as with how these are re-membered in the present. In the film Whale Rider (Caro 2002), Māori culture is seen as frozen, its perduring male dominance embodied in the patriarch Koro, but challenged by Paikea, the young girl who represents the future. Oppressive Māori patriarchy must yield to the "girl power" of a leader whose strength is derived both from her genealogical connection to divine powers and her sheer talent as a prophet of a liberating modernity. Though set in the particular place of Whangara in the North Island, this is a space without Pàkehā, evoking both the myths of the past and dreams of the future. Here an old story is told about the oppressions of traditional patriarchy and the promises of an enlightened modernity, a tale 
that occludes both the realities of Western patriarchy and the perduring gendered inequalities among Pākehā. Thus, like Hawaiian masculinities, Māori masculinities must be seen through a historical lens that highlights their colonial relation with settler masculinities, a configuration of hierarchy and hegemony that belies the promise of the bicultural contract of Aotearoa/New Zealand. ${ }^{4}$

But we might ask why such contrastive colonial discourses emerged and persisted between "emasculated" Hawaiian and "hypermasculine" Māori men. Some might find an explanation in the contrast between forms of resistance involving nonviolent petitions and protests around a usurped queen, and the violent resistance of the Māori wars and of aggressive, millennial prophecies. Some might emphasize the dynamic relation in how indigenous women were represented in colonial discourses and related to in colonial practice. Since the earliest European voyages, Hawaiian women were perceived as alluring and the place of Hawai' $i$ as warm, inviting, and feminized. Some Europeans also vaunted and exploited the allure of Māori women, and celebrated the beauties of the spectacular natural landscape of their colder, southern islands. But the sensual ease associated with a "tropical paradise" perdured in representations of Hawai'i from early European voyages to the militourism of the present (Teaiwa 1994). And so, as Tengan suggests, there is an iconic, popular cultural contrast between an inviting, feminized hula and a resistant, hypermasculine haka. The mutual perception of Hawaiian and Māori men may have been partially filtered through such a colonial lens. But it is important not to accept the colonial logic whereby the feminine equals subjugation and the masculine equals resistance. Haunani-Kay Trask's revalorization of the fiery goddess Pele surely refutes this (Jolly 2005). As many have shown, "hula girls" as much as "beach boys" are not passive objects of a colonial gaze, and the hula is as much an expression of a resistant and persistent indigeneity as the haka (see Trevor Graham's 2005 film, Hula Girls). Thus, the mutual relation of Hawaiian and Māori men, and their relations to women in their respective movements for sovereignty, deserves historical explanation that addresses the present and the future as much as the colonial past.

\section{Triangulated Figures: Masculinities in the MARTIAL / MARSHALL ISLANDS}

Again, Greg Dvorak's article stresses the importance of a relational and historical view of masculinities. But rather than conceiving historical rela- 
tions through the binary of Western and Oceanic, colonizer and colonized, he triangulates Marshallese, American, and Japanese masculinities. Grounded in his own growing up on Kwajalein Atoll in the Marshall Islands and more recent ethnographic and archival research, he plots a relation between three masculine figures: the United States Patriot, the indigenous Marshallese trickster Etao, and the Japanese Dankichi, the boyish figure of a Japanese adventurer in the South Seas derived from a popular comic of the I930s. Dvorak deploys these as dramatis personae contending in colonial and military theaters, struggling for control of the martial Marshall Islands.

Inspired by the rather different theories of performance proposed by Connell (2005), Butler (1995), and Dening (2004), Dvorak ponders how we might relate these three contending personae, figures of myth, imagination, and popular culture to the embodied experiences of real men. The Patriot is not just a missile but also a man, committed to defense of his country, the United States, his family and his way of life. In Dvorak's life story, his own father, a civilian radar engineer working at the US missile testing complex on Kwajalein in the I970s, embodies that figure, as do those men and women working for the US military today, post-September I I and the Patriot Act. But, as Dvorak stresses, that continuing mission requires both a continuing threat to national/domestic security and a suppression of contending masculinities, in this case both Marshallese and Japanese.

Marshallese men have been conscripted into being Patriots, and through the Compact of Free Association, some have negotiated continuing profitable leases of Marshallese land; some work as day laborers on Kwajalein; while others, like Hawaiians, defend the United States in more distant wars as soldiers in Iraq. They have not been abjectly complicit in this process but rather have adopted the lively cunning of the heroic mediator, whom Dvorak likens to Etao, the trickster figure of Marshallese myth. Like Walker's Hawaiian surfers, Etao has great skills, wit, intellect, and sexual allure; he can subvert the colonial hegemony of American men, and challenge the chief (irooj). Dvorak shows how the power of male chiefs has become entangled with the patriarchal power and presumption of America, in the process eroding the power of women as leaders and landowners. Men have reaped most of the benefits from US occupation, not only in jobs but also in rents from the US\$ 5 million paid to landowners. And in this neoliberal era of accountability, Dvorak concludes that performing Etao masculinity appears more tragic than heroic. 
But the present compact between American and Marshallese masculinities depends on an active forgetting, which is also a crucial part of re-membering. It is predicated on an amnesia about the Japanese; their long influence in the Marshall Islands is portrayed as a cruel moment of oppression from which the Americans "liberated" the Marshallese (see Diaz 200I). Yet as Dvorak shows, the mutual relation between Japanese and Marshallese is far deeper than the historical re-enactments on Liberation Day allow. Japanese long had an interest in the Nanyo Gunto (or South Seas Islands) as a site for imperial adventure and expansion, "fishing" not just for tuna but also for other resources. Dvorak sees this youthful, exploratory spirit of Japanese imperial expansion embodied in the comic hero of Dankichi, a solitary adventurer, like a Japanese Robinson Crusoe. Such dreams of solo tropical adventure accompanied the realities of Japanese expansion: from I9I4, Japanese villages, plantations, shops, schools, and hospitals were created in the Marshalls, and the Japanese colonial administration aspired to "civilize" just as much as the Euro-American powers did. Persisting links were sustained by tuna fishermen and by some ties of marriage and reproduction.

These deeper Japanese connections to the Marshalls are now submerged, and the privileged re-memberings are of those Japanese "boys" killed during bloody battles with the Americans in World War II. After a period of dramatic militarization of the islands in the late I930s, over 35,000 Japanese men were deployed there in World War II, and many died in battle or of starvation as supply lines were cut. The young men who died in Kwajalein are today remembered as "crushed pearls" by their grieving families. In a moving vignette of the visit by a Japanese bereavement group to Kwajalein in 2005 , Dvorak evokes the present relation between these elderly grieving Japanese and the US base commander at the time, a woman, but equally embodying the masculinity of the Patriot. The bittersweet nostalgia of Japanese defeat thus re-members masculinities as much as American celebrations of "liberation" or victory.

\section{Crossing Genders and Sexualities between THE COOKS AND FIJI}

The figure of a female US base commander embodying martial masculinity in the Marshall Islands reminds us that the Oceanic masculinities we explore in this issue are fluid, and like the "waters of men" in Carl Pao's painting, sinuously move around the "waters of women," fluid feminini- 
ties. These fluid relations have been consummately explored in recent literatures focused on "female masculinities," "male femininities," and stories of gender crossings, brilliantly analyzed by Judith Butler (I990), Marjorie Garber (I992), Niko Besnier (I994), and Tom Boellstorff (2005), and poignantly narrated by Jeffrey Eugenides $(2003) .{ }^{5}$ Central to the contributions of Besnier (1994) and Boellstorff (2005) are compelling questions about how to construe the relation between Western and non-Western genders and sexualities and whether the relations between gender and sexuality envisaged in Western models have been imperially projected onto other regions (see Jackson 1996, I997).

Kalissa Alexeyeff engages such questions about the relation between Western and Oceanic models in her discussion of a drag queen competition on Rarotonga, in the Cook Islands. Unlike many cross-dressing performances that she witnessed in the Cooks, this was adjudged a failure by the audience ("It was stink"). Alexeyeff suggests that the failure derived from a deep dissonance between Western and Cook Islands models of gender and sexuality. For her these are not simply antithetical but rather locked in an uneasy embrace of attraction and repulsion. Inspired by writers like Besnier (1994, I997, 2002) and Peter A Jackson (I996), she critically interrogates the globalization of Western sexual identities that Dennis Altman depicted (200I). Cook Islanders do not mimic but rather appropriate and domesticate Western and cosmopolitan modes of gender and sexuality for local purposes. And, as Alexeyeff's example shows, the "friction" (Tsing 2005) generated by cross-cultural encounters is not always productive of "happy hybridity."

Alexeyeff stresses how laelae in the Cooks are not the same as "gay" or homosexual men in countries like Australia or North America. They desire not other laelae but "straight men" who, though sexual partners, do not identify as laelae or homosexual. Some laelae identify as women trapped in men's bodies, while some identify as a distinct category of person. Their styles of clothing and comportment are very varied. The fluidity of their gender and sexual identities is at odds with Western categorizations, which rely on tighter definitions of men and women, heterosexual and homosexual identities. Given the density of connections to families in New Zealand, Tahiti, and North America, Cook Islanders are very aware of such Western categories and practices, and they humorously play with the differences (for example, punning on the meaning of "queen"). But ultimately they celebrate their own cultural configurations, where, Alex- 
eyeff suggests, gender is a far more important aspect of the person than sexuality.

In the drag queen competition Alexeyeff analyzes, discomfort was generated around the fondling of breasts, breast-feeding, and the birth of a "dog-child." Although the show was modeled on Western drag, ultimately this performance of cross-dressing depended on incommensurable models of gender and sexuality, and expelled foreign elements to consolidate the borders of what was locally thought good and appropriately hilarious. Thus, despite the facts that more Cook Islanders live in New Zealand than the Cooks and that all are familiar with global popular culture, local models of gender and sexuality have not been eclipsed by a neo-imperial "global sex."

The final article in this issue, by Nicole George, again questions the relation between Western and Oceanic models of gender and sexuality, not in such a deconstructive way, but by comparing the differential tolerance accorded homosexuality and aggressive hypermasculinity in the context of contemporary Fiji. George was pursuing her doctoral research soon after the coup of 2000, which involved the hostage-taking of then Prime Minister Mahendra Chaudry and members of his government and the rejection of the 1997 constitution, which had valorized multicultural tolerance and outlawed discrimination on the basis of sexuality. This unusual constitutional recognition of the rights of sexual minorities had occasioned a huge public backlash, in which conservative nationalists condemned homosexual and transgendered people and practices.

As George shows, much of this condemnation-that homosexuality was "unnatural," a "sin," or a "curse," even deserving of the death penalty-from politicians and church leaders alike relied on the strong historical link forged between state and church, particularly between indigenous nationalist interests and Methodism. Homophobic sentiments were especially ventilated in high-profile court cases around the murders of John Scott and his partner George Scrivener in 200I, and the High Court's overturning of the conviction of an Australian tourist on sodomy offenses in 2005. Transnational coalitions were no doubt at work on both sides, those who espoused gay rights as part of individuals' rights to liberty and privacy and those who promoted conservative Christian agendas.

George deftly compares the intolerance and lack of compassion for gay and transgendered people with the extraordinary tolerance accorded to expressions of masculine violence shown by both military and civilians 
during the events of the 2000 coup. Apart from the violence of the hostage-taking, looting, arson, and rape, enormous fear and insecurity were generated among those Indo-Fijian families whose farms and businesses were especially targeted by threats from marauding gangs of young Fijian men, many of whom were recruited and paid by the backers of Speight's coup (see Emde 2005; Pangerl 2007). Investigations were launched into more than two hundred fifty identified rebel supporters, but for the most part they escaped retribution and, unlike some of the major coup leaders, they received lenient or no penalties. The coalition government of Qarase and the Labour Party elected in June 2006 looked set to continue on a path of reconciliation. Indeed, George reports, many expressed tolerance and even sympathy with their violent behavior. Sitiveni Rabuka, leader of the 1987-88 coups, and erstwhile prime minister, described the looting and violence as expected and natural.

Such violent, aggressive behavior on the part of young men might be described as "hypermasculine" rather than that "hegemonic" masculinity, embodied by the politicians and the pastors in their formal sulus (tailored wraparound garments). But there is no doubt a relation-and one might say a coalition—of interests here. Originally written in mid-2006, George's article concluded on a more hopeful note, observing how gay activists were later returning to more forthright public engagements, even playfully reclaiming the sulu, that symbol of hegemonic Fijian, Christian masculinity in Fiji. Although strongly supported by transnational movements for human and gay rights, these activists were thereby also claiming to be part of the mainstream of Fijian masculinities. But as her 2007 postscript suggests, it is doubtful whether that hope will be sustained. For, as with the histories of Oceanic masculinities in general, the situation in Fiji is fluid, if not turbulent, for the immediate future.

\section{POSTSCRIPTS FROM FiJi: FLUIDITY OR FIXITY IN Oceanic Masculinities?}

As I was finishing this introduction, I had just returned to my hotel room in Suva from the July 2006 "Vaka Vuku" conference at the University of the South Pacific. During that week on the USP campus (admittedly a zone of local tolerance), I witnessed a continuation of public challenges to hegemonic Oceanic masculinities articulated by a number of speakers, including both men and women from Christian churches. The broader themes explored in this special issue were also articulated in the creative 
expressions that were an integral part of that conference. So let me conclude with some impressions of the performances designed by choreographer Alan Allo and the dance troupe of the Oceania Centre for Arts and Culture. In a statement during the final plenary, Alan celebrated his unique fa'afafine identity, claiming he was neither male nor female but a distinct person, valued by his Samoan family and his community. ${ }^{6}$ We saw a video of the several painful days during which he acquired his pe'a, the tatau iconic of hegemonic Samoan masculinity and cultural survival. In the final dance performances we saw creolized Pacific and Celtic forms, in stunning, zesty moves, which flowed effortlessly from Riverdance to the Oceanic. They concluded with a brilliant dance, with women dressed in white, men in black, and other, more "feminized" men in the middle, in sinuous, silver sulus. Dance styles alternated among masculine, feminine, and fa'fafine modes, with suggestive brushings and conjugations between different couples. The remarkable erotic energy, fluidity, and virtuosity thrilled the audience. Epeli Hau'ofa, author of that influential new vision of Oceania (1993), and founder of the Oceania Centre for Arts and Culture, nodded with approving relish.

But several months after the preceding optimistic paragraph, as I was revising this essay back in Canberra in December 2006, Fiji experienced another coup, this time led by Commodore Frank Bainimarama (see George, this issue). The future of Oceanic masculinities in the Pacific, at least in Fiji, now seems less of a freewheeling, creative performance, and still intimately entangled with displays of violent masculine force, grounded in the imperial hybrid of the Fijian military (see Teaiwa 2005), even if this time it has been allegedly deployed in the service of racial equality, anticorruption, and good governance. ${ }^{7}$

Heartfelt thanks to participants in the conference "Moving Masculinities: Crossing Regional and Historical Borders" and the contributors to this issue for their inspiration. The "Moving Masculinities" conference was held at the Australian National University from 29 November-2 December 2005. It was sponsored by the Gender Relations Centre, Research School of Pacific and Asian Studies, funded in large part by a grant from the Australian Research Council, "Oceanic Encounters: Colonial and Contemporary Transformations of Gender and Sexuality in the Pacific" (DPO45I620), and convened by Richard Eves and an advisory board that included Margaret Jolly and John P "Jack" Taylor. Taylor also convened a related workshop the previous day centered on changing Pacific masculinities (many of which are forthcoming in The Australian Journal of Anthropology). All 
of the papers in this issue were originally presented at either of these two events. I also thank the two anonymous referees for their constructive suggestions and Michelle Antoinette, Lia Szokalski, and Jan Rensel for their meticulous creativity in copyediting and securing good quality images. Finally, thanks to the journal editor and the editorial board for their enthusiasm about this collection.

\section{Notes}

I See Tuzin I997 for a poignant but problematic lament, and Knauft I 997 for a more critical evaluation.

2 I use quotes to flag the colonial infantilization of these men, who were way past childhood.

3 As Walker stresses, he'e nalu was practiced in the past by both men and women, chiefs and commoners, although there was a sense in which the powers and skills of surfing well were connected to nobility and even to royalty.

4 Note that Hokowhitu prefers not to use this formulation, since he believes that Aotearoa was never an indigenous concept and the generic colonial label imputes a spurious precontact homogeneity and unity to Māori.

5 Eugenides' 2003 novel Middlesex situates a poignant personal story of transsexualism in the United States in the context of the Greek diasporic experience and the epoch of the late I96os. During this period several scholars working on hermaphroditism and gender liminality made an influential distinction between sex and gender. Psychiatric and surgical interventions to redress "gender dysporia” were gaining legitimacy, but Eugenides' protagonist refuses these, rather embracing the fluidity of a gender liminal state. My thanks to Rena Lederman for introducing me to this superb book.

6 Fa'afafine means "in the manner of a woman" in Samoan and refers to gender liminal persons born men but behaving as women (see, eg, Mageo I992, I996). It parallels the Tongan fakaleiti, analyzed in Besnier I994, I997, and 2002.

7 A workshop convened at the Australian National University on 5 June 2007 graphically revealed the extent of the climate of fear in Fiji occasioned by the interim government headed by Bainimarama, the infiltration of the military into the ranks of the public service, and the divisions generated among nongovernmental and human rights organizations as a result of the December 2006 coup.

\section{References}

Allen, Michael

I967 Male Cults and Secret Initiations in Melanesia. Melbourne: Melbourne University Press. 
I998 Male Cults Revisited: The Politics of Blood Versus Semen. Oceania 68

Altman, Dennis

(3): I89-I99.

200I Global Sex. Sydney: Allen \& Unwin.

Besnier, Niko

I994 Polynesian Gender Liminality in Time and Space. In Third Sex, Third Gender: Beyond Sexual Dimorphism in Culture and History, edited by Gilbert Herdt, 285-328. New York: Zone Books.

I997 Sluts and Superwomen: The Politics of Gender Liminality in Urban Tonga. Ethnos 62 (I-2): 5-3I.

2002 Transgenderism, Locality, and the Miss Galaxy Beauty Pageant in Tonga. American Ethnologist 29 (4): 534-566.

Boellstorff, Tom

2005 The Gay Archipelago: Sexuality and Nation in Indonesia. Princeton, Brison, Karen NJ: Princeton University Press.

I995 Changing Constructions of Masculinity in a Sepik Society. Ethnology

Butler, Judith $34(3):$ I $55-$ I 75 .

I990 Gender Trouble: Feminism and the Subversion of Identity. New York: Routledge.

I995 Bodies that Matter. Berkeley: University of California Press.

Caro, Niki, director

2002 Whale Rider. Feature film. South Pacific Pictures/Apollo Media GmbH and Co 5 .

Connell, R W

I995 Masculinities. Berkeley: University of California Press.

2000 The Men and the Boys. Cambridge: Polity Press.

2005 Masculinities. Second edition. Berkeley: University of California Press.

Dening, Greg

2004 Beach Crossings. Melbourne: Miegunyah Imprint at Melbourne University Press.

Desmond, Jane

I999 Staging Tourism: Bodies on Display from Waikiki to Sea World. Chicago: University of Chicago Press.

Diaz, Vicente

200I Deliberating Liberation Day: Memory, Culture and History in Guam. In Perilous Memories: The Asia-Pacific War(s), edited by Takahashi Fujitani, Geoffrey M White, and Lisa Yoneyama, I 55-180. Durham, NC: Duke University Press.

2002 "Fight Boys Till the Last": Football and the Remasculinization of Indigeneity in Guam. In Pacific Diaspora: Island Peoples in the United 
States and the Pacific, edited by Paul Spickard, Joanne Rondilla, and Deborah Hippolite Wright, I67-194. Honolulu: University of Hawai'i Press.

Donaldson, Mike

I993 What is Hegemonic Masculinity? Theory and Society 22: 643-667.

Dowsett, Gary

2006 Moving Masculinities and Social Change: Why Do Men Matter? Gender

Relations Centre Working Paper 20. Originally presented as keynote paper at the "Moving Masculinities: Crossing Regional and Historical Borders" international conference hosted by the Gender Relations Centre, The Australian National University, Canberra, 29 Nov-2 Dec 2005 .

Elliston, Deborah

I995 Erotic Anthropology: "Ritualized Homosexuality" in Melanesia and Beyond. American Ethnologist 22 (4): 848-867.

Emde, Sina

2005 Feared Rumours and Rumours of Fear: The Politicisation of Ethnicity During the Fiji Coup in May 2000. In Relations in Multicultural Fiji: Transformations, Positionings and Articulations, edited by Elfriede Hermann and Wolfgang Kempf. Special issue of Oceania 75 (4):387402 .

Eugenides, Jeffrey

2003 Middlesex. Waterville, ME: Thorndike Press.

Ferguson, Kathy E, and Phyllis Turnbull

I999 Oh Say, Can You See? The Semiotics of the Military in Hawai'i. Minneapolis: University of Minnesota Press.

Fife, Wayne

I995 Models for Masculinity in Colonial and Postcolonial Papua New Guinea. The Contemporary Pacific 7:277-302.

Forster, Johann Reinhold

I996 Observations Made during a Voyage Round the World. New edition, edited by Nicholas Thomas, Harriet Guest, and Michael Dettelbach. Honolulu: University of Hawai'i Press.

Garber, Marjorie

I992 Vested Interests: Cross-dressing and Cultural Anxiety. New York: Routledge.

George, Nicole

2006 Situating Agency: Gender Politics and Circumstance in Fiji. PhD thesis, International Relations, Research School of Pacific and Asian Studies, The Australian National University.

Godelier, Maurice

I986 The Making of Great Men: Male Domination and Power Among the New Guinea Baruya. Cambridge, Uk: Cambridge University Press. 
Godelier, Maurice, and Marilyn Strathern, editors

I99I Big Men and Great Men: Personifications of Power in Melanesia. Cambridge, uk: Cambridge University Press.

Graham, Trevor, director

2005 Hula Girls: Imagining Paradise. Documentary for sBs Television. DvD, 52 minutes. Producer Andrew Ogilvie. Australia: Electric Pictures Pty Ltd.

Hau'ofa, Epeli

I993 Our Sea of Islands. In A New Oceania: Discovering Our Sea of Islands, edited by Eric Waddell, Vijay Naidu, and Epeli Hau'ofa, 2-I6. Suva: School of Social and Economic Development, The University of the South Pacific, and Beake House.

Herdt, Gilbert

I98 I Guardians of the Flutes: Idioms of Masculinity. New York: McGrawHill.

I987 The Sambia: Ritual and Gender in New Guinea. New York: Holt, Rinehart and Winston.

Herdt, Gilbert, editor

I982 Rituals of Manhood: Male Initiation in Papua New Guinea. Berkeley: University of California Press.

I984 Ritualized Homosexuality in Melanesia. Berkeley: University of California Press.

Hokowhitu, Brendan

2004 Tackling Māori Masculinity: A Colonial Genealogy of Savagery and Sport. The Contemporary Pacific I 6:259-284.

Jackson, Peter A

I996 The Persistence of Gender. Meanjin 55 (I): I I 8-I I9.

I997 Kathoey $><$ Gay $><$ Man: The Historical Emergence of Gay Male Identity in Thailand. In Sites of Desire, Economies of Pleasure: Sexualities in Asia and the Pacific, edited by Lenore Manderson and Margaret Jolly, I66-I92, notes 3I2-3 I4. Chicago: University of Chicago Press.

Jolly, Margaret

I992a "Ill-natured Comparisons": Racism and Relativism in European Representations of ni-Vanuatu from Cook's Second Voyage. History and Anthropology 5 (3/4): 33 I-364.

I992b Women of the Place: Kastom, Colonialism and Gender in Vanuatu. Chur, Switzerland: Harwood Academic Press.

I997 From Point Venus to Bali Ha'i: Eroticism and Exoticism in the Pacific. In Sites of Desire, Economies of Pleasure: Sexualities in Asia and the Pacific, edited by Lenore Manderson and Margaret Jolly, 99-I 22, notes 303-307. Chicago: University of Chicago Press.

2005 Beyond the Horizon? Nationalisms, Feminisms, and Globalization in 
the Pacific. In Outside Gods: History Making in the Pacific, edited by Martha Kaplan. Special issue of Ethnohistory 52 (I):I37-I 66.

2007 Imagining Oceania: Indigenous and Foreign Representations of a Sea of Islands. The Contemporary Pacific I9:508-545.

Kauanui, J Kēhaulani

I998 Off-island Hawaiians "Making” Ourselves at "Home”: A (Gendered) Contradiction in Terms? In Migrating Feminisms: The Asia/Pacific Region, edited by Kalpana Ram and J Kēhaulani Kauanui. Special issue of Women's Studies International Forum 2I (6): 68 I-695.

Keesing, Roger

I 985 Killers, Big Men, and Priests on Malaita: Reflections on a Melanesian Troika System. Ethnology 24:237-252.

Kempf, Wolfgang

2002 The Politics of Incorporation: Masculinity, Spatiality and Modernity

Knauft, Bruce Among the Naing of Papua New Guinea. Oceania 73 (I): 56-77.

I997 Gender Identity, Political Economy and Modernity in Melanesia and Amazonia. The Journal of the Royal Anthropological Institute 3 (2): 233-259.

Law, Robin, Hugh Campbell, and John Dolan, editors

I999 Masculinities in Aotearoa/New Zealand. Palmerston North, NZ: Dunmore Press

Layard, John

I942 Stone Men of Malekula. London: Chatto \& Windus.

Linnekin, Jocelyn

I997 Consuming Cultures: the Commoditization of Cultural Identity in the Island Pacific. In Tourism, Ethnicity and the State in Asian and Pacific Societies, edited by Michel Picard and Robert E Wood, 2I5-250. Honolulu: University of Hawai'i Press.

Lipsett, David

I997 Mangrove Man: Dialogics of Culture in the Sepik Estuary. Cambridge, uK: Cambridge University Press.

Mageo, Jeannette M

I992 Male Transvestism and Cultural Change in Samoa. American Ethnologist I 9:443-459.

I996 Samoa, on the Wilde Side: Male Transvestism, Oscar Wilde, and Liminality in Making Gender. Ethos 24 (4): 588-627.

O’Brien, Patty

2006 The Pacific Muse: Exotic Femininity and the Colonial Pacific. Seattle: University of Washington Press.

Osorio, Jonathan Kamakawiwo'ole

2002 Dismembering Lähui: A History of the Hawaiian Nation to 1887. Honolulu: University of Hawai'i Press. 
Pangerl, Markus

2007 Notions of Insecurity among Contemporary Indo-Fijian Communities. The Asia Pacific Journal of Anthropology 8 (3): 25 I-264.

Sahlins, Marshall

I963 Poor Man, Rich Man, Big Man, Chief: Political Types in Melanesia and Polynesia. Comparative Studies in Society and History 5:285-303.

Said, Edward W

I978 Orientalism. London: Routledge and Kegan Paul.

Silverman, Eric Kline

200I Masculinity, Motherhood, and Mockery: Psychoanalyzing Culture and the Iatmul Naven Rite in New Guinea. Ann Arbor: University of Michigan Press.

Strathern, Marilyn

I988 The Gender of the Gift: Problems with Women and Problems with Society in Melanesia. Berkeley: University of California Press.

Teaiwa, Teresia

I994 bikinis and other s/pacific n/oceans. The Contemporary Pacific 6:87I09.

2005 Articulated Cultures: Militarism and Masculinities in Fiji during the mid-I990s. Fijian Studies: A Journal of Contemporary Fiji 3 (2): 20I222.

Tengan, Ty P Kāwika

2002 (En)gendering Colonialism: Masculinities in Hawai'i and Aotearoa. Cultural Values 6 (3): 229-238.

forthcoming Native Men Remade: Gender and Nation in Contemporary Hawai'i. Durham, NC: Duke University Press.

Trask, Haunani-Kay

I993 From a Native Daughter: Colonialism and Sovereignty in Hawai'i. Monroe, ME: Common Courage Press.

I996 Feminism and Indigenous Hawaiian Nationalism. Signs: Journal of Women in Culture and Society 2I (4): 906-9 I 6.

Tsing, Anna

2005 Friction: An Ethnography of Global Connection. Princeton, NJ: Princeton University Press.

Tuzin, Donald

I997 The Cassowary's Revenge: The Life and Death of Masculinity in a New Guinea Society. Chicago: University of Chicago Press.

Walker, Isaiah

2005 Terrorism or Native Protest: The Hui 'O He'e Nalu and Hawaiian Resistance to Colonialism. Pacific Historical Review 74 (4): 575-60 I.

White, Geoffrey M and Lamont Lindstrom, editors

I989 The Pacific Theatre: Island Representations of World War II. Pacific 
Islands Monographs Series 8. Honolulu: University of Hawai'i Center for Pacific Islands Studies and University of Hawai'i Press.

Worth, Heather, Anna Paris, and Louisa Allen, editors

2002 Life of Brian: Masculinities, Sexualities and Health in New Zealand. Dunedin, NZ: University of Otago Press.

\section{Abstract}

Past studies of Oceanic masculinities have tended to see masculinity in the singular, through the lens of unchanging cultural traditions, wherein types of men were iconic of cultural differences. This special issue considers masculinities in the plural, both within and between cultures, exploring the relations between hegemonic and subordinate masculinities and how masculinities are configured in the context of colonial histories, militarism, and globalization. It connects a historical and relational approach to masculinities to embodied experience and individual and collective memories across the diversity of Oceania.

KEYWORDS: masculinities, Oceania, histories, bodies, sexualities, militarism, colonialism 